\title{
Optimum Parameters for the Formulation of Charcoal Briquettes Using Bagasse and Clay as Binder
}

By

J.M. Onchieku' (D.Phil), B.N. Chikamai ${ }^{1}(\mathrm{PhD})$ and M.S. Rao ${ }^{2}(\mathrm{PhD})$

\begin{abstract}
Kenya generates about 1.6 million tones of sugarcane bagasse which has enormous potential for exploitation in modern commercial applications. Due to rising fossil fuel prices, availability in large quantity and rapidly growing interest in bio-energy as well as technological advances and environmental concerns, bagasse could be utilized for the formulation of charcoal briquettes for household use to supplement wood charcoal. In this study briquettes were formulated using carbonized bagasse, clay as a binder and molasses as a filler. Bagasse was obtained from sugar factories for carbonization. Carbonization was carried out using a brick-built kiln while blending used a manually operated drum mixer. A piston type briquetting press fitted onto a universal strength testing machine was used for the production of briquettes. The most optimum parameters that produced briquettes which complied to current charcoal specifications for household use were in the ratio of 1:1:40 for molasses, clay and carbonized bagasse respectively at $0.50 \mathrm{~N} / \mathrm{mm}^{2}$ pressure. At this formulation, briquettes were produced whose ash content, volatile matter and calorific energy were $36.4 \%, 27.2 \%$ and $4.390 \mathrm{Kca} / \mathrm{g}$ respectively. The briquettes produced burnt without sparks and were smokeless, producing no irritating smell. They ignited easily and took relatively long before they extinguished. They were recommended for household use in Kenya.
\end{abstract}

\section{Introduction}

Energy, which is important for the provision of essential services for humanity such as lighting, heating and cooking, is broadly classified into renewable and nonrenewable. The demand for the former which include hydro-power, geothermal, biomass, solar, wind and tidal energy, has been increasing over the years in the 
developing countries where 1.8 million people in rural and urban centers lack access to commercial energy (UNEP, 2000).

Biomass energy accounts for about $14 \%$ of the total world energy compared to coal $(12 \%)$, natural gas $(15 \%)$ and electric energy (14\%). In East Africa $84 \%$ of the total energy used by $90 \%$ of the population is derived from biomass sources such as charcoal, firewood, agricultural residues and animal/livestock wastes. Between 1970 and 1994, production and consumption of charcoal doubled and is expected to increase by $5 \%$ up to the year 2010 (WEC, 2003).

In Kenya, biomass energy is cheaper (USD 261 p.a.) than the cost of kerosene (USD 360 p.a.), liquefied petroleum gas (LPG, USD 397 p.a.) and electricity (USD p.a. 747). About 2.4 million tones of charcoal which is equivalent to 120,000 ha of woodland is consumed annually (GOK, 2002). This was at an estimated per capita consumption of $156 \mathrm{Kg}$ and $152 \mathrm{Kg}$ of charcoal in the urban and rural areas respectively. According to the rural and urban household energy survey by Mwichabe (1999), about 40 million GigaJoules (GJ) equivalent of energy was derived from farm residues comprising of vegetative materials from diverse agricultural operations and processes.

At this rate of consumption, the traditional sources of biomass energy which include woodlands and shrublands -37.6 million ha; farmlands and settlements 9.5 million ha; indigenous forests -1.2 million ha; and plantation forests -0.2 million ha are diminishing at an alarming rate of $10 \%$ per annum without replenishment leading to accelerated desertification and increased soil loss caused by devegetation and desertification.

Because of the foregoing scenario, there is need to introduce alternative and improved bio-energy such as charcoal briquettes produced from agricultural and forest-based residues. Charcoal briquettes are any solid biomass charcoal made by thoroughly mixing powdered charcoal (charcoal fines) produced from any organic material with a binder and/or inorganic additives called fillers (Emrich, 1984).

Kenya, which is basically an agro-based economy with agricultural operations and processes contributing over $80 \%$ of Gross Domestic Product (GDP), generates large quantities of agricultural, agri-industrial residues with limited industrial applications. The potential for the exploitation of these residues is enormous due to (a) rising fossil fuel prices (b) their availability in relatively high abundance (c) their availability at almost zero cost and (d) their contribution to environmental protection and conservation (Massaquoi, 1990). 
Bagasse is one of the most important factory crop residues in the country. It is the fibrous residue obtained as a by-product when sugarcane is crushed in factories used to a limited extent for the generation of electricity and process heat for internal use. The bulk of bagasse from all factories is considered an environmental hazard and a probable source of factory fires. It is usually difficult to decompose so as to be used as composite manure. Its potential for commercial use as a raw material for the formulation of charcoal briquettes is enormous due to the rapidly growing interest in energy derived from biomass residues and also due to local and global environmental concerns and technological advances. Commercial charcoal briquettes would also supplement charcoal produced from natural and plantation forests.

It is estimated that currently about 1.6 million tones of bagasse is generated annually in Kenya although potentially about 2.6 million tones could be generated. Out of this quantity only $25 \%$ is economically utilized for the generation of process heat for internal use in factory boilers. The factories not only incur huge operational costs in transporting bagasse to dumpsites but the residues also pose many environmental problems and impact negatively on human health and safety (Onchieku et al, 2005).

The formulation of charcoal briquettes from bagasse is further justified because of its low or zero value yet concentrated at points of processing; its availability throughout the year with minimal storage problems and at almost bone-dry condition; and its continuous supply for years a head to allow successfully armotization of the plant used for production of the briquettes (FAO, 1995).

The objectives of this study was to determine optimum parameters for the formulation of briquettes using molasses, clay and bagasse, their physico-chemical properties and burning and utilization characteristics of the briquettes for household use.

\section{Methods and materials}

In this study sugarcane bagasse was used in formulating charcoal briquettes because of its availability in large quantities and at almost zero-cost, its negative environmental importance and the suitability of its energy parameters for the formulation of briquettes. Samples were obtained from Nzoia, Mumias, Chemelil, Muhoroni and Sony sugar factories. Sampling was systematically carried out such that fresh bagasse samples were collected from various points within the 
dumpsites. They were dried on direct sunlight to reduce moisture content from about $50 \%$ to less than $18 \%$ before being carbonized. This was important in saving on the cost of energy used during carbonisation.

Figure 1 shows a brick-built kiln that was used to carbonise the dry bagasse. The kiln was designed such that bagasse decomposed from its complex state into simpler elements in limited quantities of oxygen into charcoal fines and other byproducts. After carbonisation, the charcoal fines obtained were pulverised into powder form using a machine which was designed and fabricated to operate on the principles of a posho-mill. Clay soil that was used as a binder was also pulverised using the same machine. Pulverisation of the carbonized bagasse and clay was necessary to increase the surface area of the components to enable thorough bonding during blending. Clay was obtained from Bokhoria swamp sites near Nzoia township. Molasses that was obtained from Chemelil factory was used as a filler and an ignition enhancer of the briquettes.

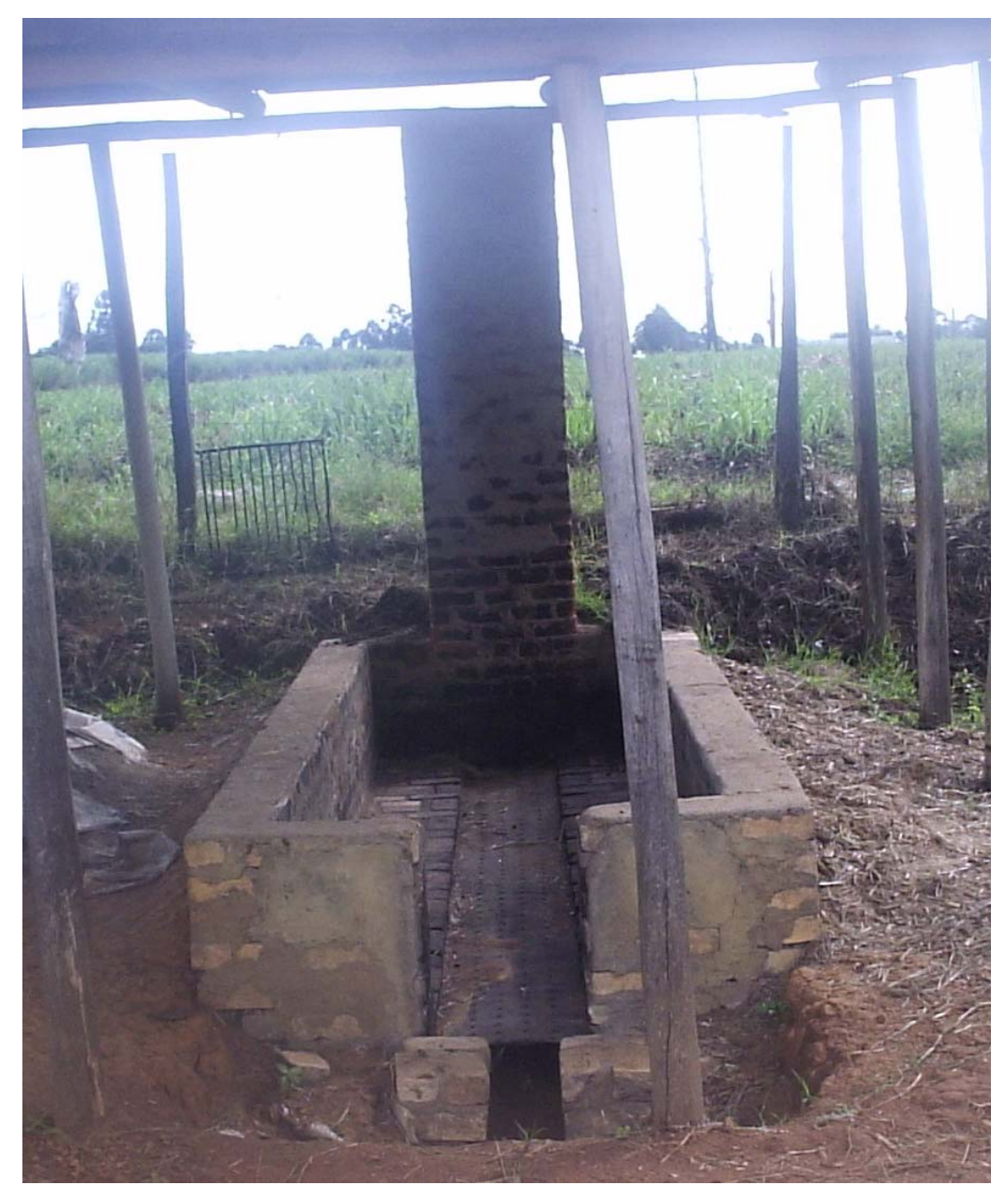

Figure 1. Brick-built kiln used for carbonizing bagasse 
Blending of the carbonised bagasse powder with clay and molasses was carried out using a drum mixer operated manually as shown in Figure 2. The blender was designed and fabricated at Kenya Forestry Research Institute (KEFRI) workshop. The blender provided extra retention time to guarantee complete blending of carbonized bagasse with the binder and other additives. Thorough mixing reduces the quantity of binder used considerably. Careful selection of clay as a binder was important since it contributes significantly to the total production cost of the briquettes. Small quantity of water was also sprinkled into the ingredients to provide extra retention medium and guarantee maximum bonding.

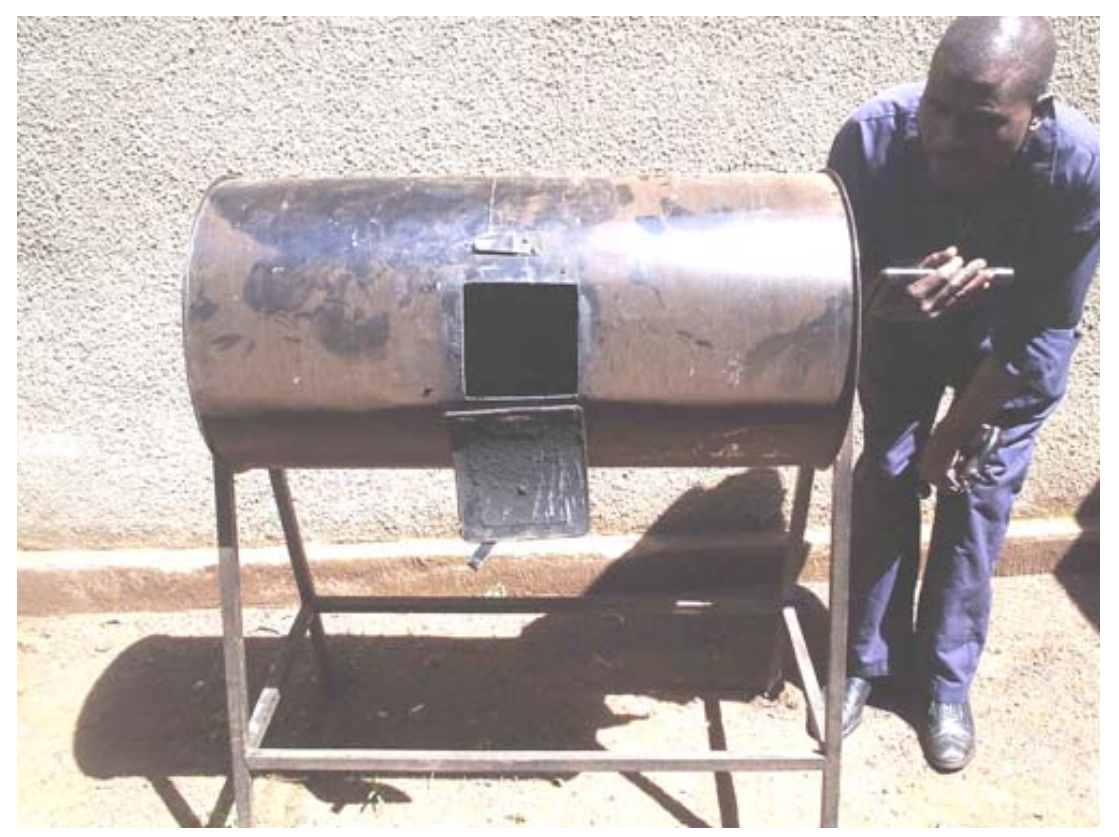

Figure2. Manually operated drum mixer for blending carbonized bagasse and clay

Table 1 shows the carbonised bagasse and additives that were formulated using different ratios of carbonized bagasse, clay and molasses and pressure. Briquettes were produced using ratios of 1:2:20 and 1:1:40 for molasses, clay and carbonized bagasse respectively. The ratio of different components were arrived at after several pre-trials and the briquettes produced tested for various parameters and burning characteristics. The pre-trial results indicated that the lower the proportion of clay, the better the performance of the briquettes. A range of 0.25 , $0.50,0.75$ and $1.00 \mathrm{~N} / \mathrm{mm}^{2}$ pressure was applied using a piston press. For each trial, a replica of four sample briquettes were produced using a combination of different ratios and pressure. 
Table 1. Ratio of ingredients and pressure used in making briquettes

\begin{tabular}{lcccc}
\hline Parameter & Mollasses & Clay & Carbonised bagasse & $\begin{array}{c}\text { Pressure, } \\
\mathbf{N} / \mathbf{m m}^{2}\end{array}$ \\
& 1 & 2 & 20 & 0.25 \\
\hline Trial 1 & 1 & 2 & 20 & 0.50 \\
Trial 2 & 1 & 2 & 20 & 0.75 \\
Trial 3 & 1 & 2 & 20 & 1.00 \\
Trial 4 & 1 & 1 & 40 & 0.25 \\
Trial 5 & 1 & 1 & 40 & 0.50 \\
Trial 6 & 1 & 1 & 40 & 0.75 \\
Trial 7 & 1 & 1 & 40 & 1.00 \\
Trial 8 & & & & \\
\hline
\end{tabular}

The thoroughly blended components in various ratios were compressed into cylindrical briquettes measuring $14 \mathrm{~mm}$ diameter and lengths not exceeding 150 $\mathrm{mm}$. The pressing was carried out using a universal strength testing machine with $500 \mathrm{KN}$ capacity at various pressures and loading rates.

The cross-head of the universal machine was fitted with a piston briquetting press that was designed and fabricated at KEFRI workshop. The briquetting press had four struts each with cross-sectional area of about $1200 \mathrm{~mm}^{2}$ that fitted very closely with metal tubes containing the components making the briquettes. The briquetting press was useful because it permits solidifying of the mixture which was achieved by raising pressure.

The trial briquettes produced were kept in stationery drying chambers and dried on direct sunlight to about $18 \%$ moisture content. They were tested in accordance to SABS (2000) for ash content, volatile matter and calorific energy value to evaluate their suitability for household use. 
The briquettes were also tested for their burning characteristics using an improved "jiko" (stove) and $2 \mathrm{~kg}$ of the charcoal. The charcoal briquettes were used to heat $2000 \mathrm{mls}$ of water to boiling point within which, the time taken to light the charcoal, the water to boil and the charcoal to extinguish was recorded. Observations were also made on the level of smokeness, sparking, odour and the type of flame. A comparison was made between charcoal briquettes, Kahawa coal which are briquettes produced using coffee husks and charcoal carbonized using mature Eucalyptus grandis. Kahawa coal was used because it is produced using agricultural residues while Eucalyptus grandis was used because its physicochemical properties, burning and utilization characteristics are much better for household use.

\section{Results and discussion \\ Formulation of charcoal briquettes}

The components that were used for the formulation of briquettes were bagasse, clay and molasses. During carbonization of bagasse, it was found that 5 bags of raw bagasse was used to produce 1 bag of carbonised bagasse. This implied that if one ton of charcoal briquettes are produced, five tones of raw bagasse have to be used. With Kenya generating about 1.6 million tones of bagasse annually, this means that about 288,000 tones of charcoal briquettes could be produced annually based on a ratio of $5: 1$ raw bagasse to carbonized bagasse and assuming that 90 $\%$ was utilized annually. This is about 8.3 million bags, each weighing $35 \mathrm{~kg}$, of charcoal briquettes produced annually from carbonized bagasse. Since Kenya uses about 2.4 million tones annually of charcoal produced from forest-based sources, charcoal briquettes from bagasse would reduce pressure on deforestation and enhance environmental protection and conservation.

\section{Physical properties of bagasse and clay formulated briquettes}

Figure 3 and Table 2 give average weight, length and computed bulk density of various briquettes produced using a series of formulations of molasses, clay and carbonized bagasse at varying pressures. The cross-sectional area of the briquettes was constant at $154 \mathrm{~mm}^{2}$ on a cylindrical base measuring $14 \mathrm{~mm}$ diameter. For the two formulations of $1: 2: 20$ and $1: 1: 40$, the briquette lengths decreased with increasing pressure. The minimum and maximum lengths were $110.9 \mathrm{~mm}$ and $120.7 \mathrm{~mm}$ for the $1: 2: 20$ formulation and $118.7 \mathrm{~mm}$ and 127.7 


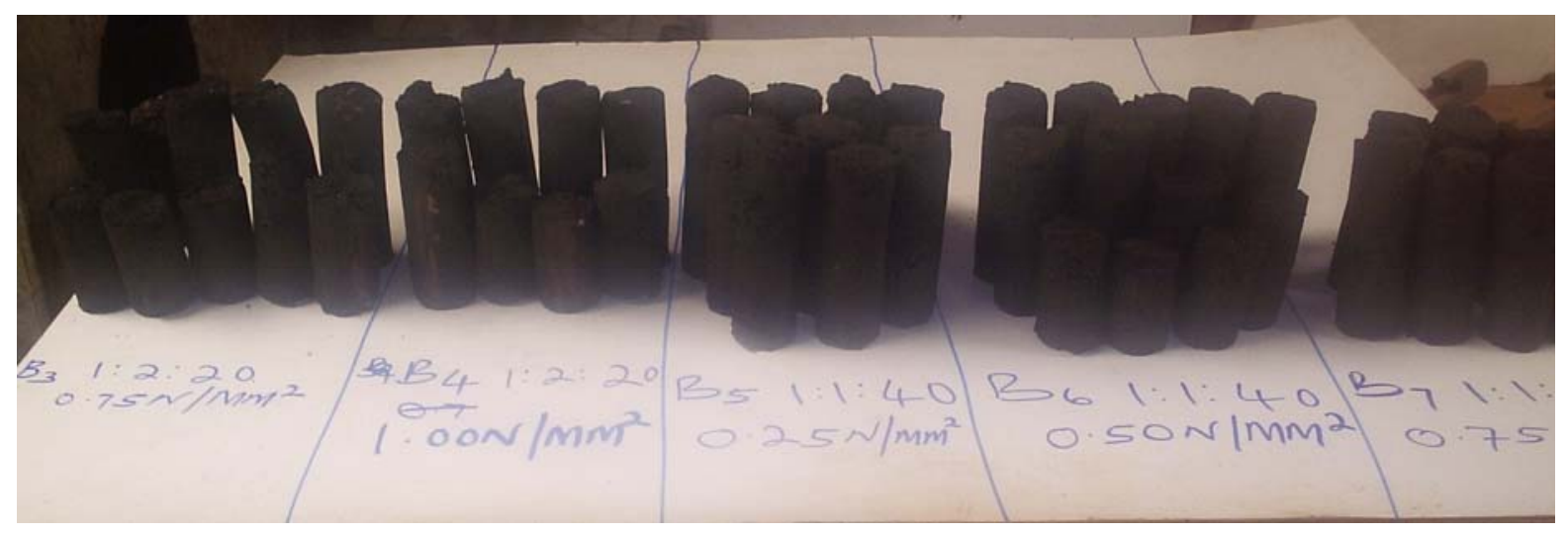

Figure 3. Various briquettes produced using different ratios and pressures

mm for the $1: 1: 40$ formulation respectively. The average briquette weight were generally higher for the 1: 2: 20 formulation which ranged between $100.4 \mathrm{~g}$ and $120.7 \mathrm{~g}$ than for the $1: 1: 40$ formulation which ranged between $87.7 \mathrm{~g}$ and 94.7 g. This was probably due to higher proportion of clay in the former than in the latter.

It was also found that the minimum and maximum bulk density for the $1: 2: 20$ formulation was $0.018 \mathrm{~g} / \mathrm{mm}^{2}$ and $0.022 \mathrm{~g} / \mathrm{mm}^{2}$ respectively while it was 0.017 $\mathrm{g} / \mathrm{mm}^{2}$ for the $1: 1: 40$ formulation of molasses, clay and carbonized bagasse. There was evident variation in bulk density between formulations which was attributed the varying proportions of clay.

Table 2. Physical properties of the formulated briquettes

\begin{tabular}{ccccc}
\hline $\begin{array}{l}\text { Molasses: clay: carbonized bagasse } \\
\text { formulation }\end{array}$ & $\begin{array}{l}\text { Pressure, } \\
\mathrm{N} / \mathrm{mm}^{2}\end{array}$ & $\begin{array}{l}\text { Length, } \\
\mathrm{mm}\end{array}$ & Weight, $\mathrm{l}$ & $\begin{array}{l}\text { Bulk } \\
\mathrm{g} / \mathrm{mm}^{2}\end{array}$ \\
\hline $1: 2: 20$ & 0.25 & 120.0 & 113.5 & 0.022 \\
& 0.50 & 120.7 & 116.0 & 0.022 \\
& 0.75 & 120.1 & 95.0 & 0.018 \\
& 1.00 & 110.9 & 100.4 & 0.021 \\
\hline $1: 1: 40$ & 0.25 & 127.7 & 93.8 & 0.017 \\
& 0.50 & 126.3 & 94.7 & 0.017 \\
& 0.75 & 118.7 & 87.7 & 0.017 \\
\hline
\end{tabular}

\section{Physico-chemical properties of charcoal briquettes}

The average moisture content, volatile matter content, ash content and calorific energy of charcoal briquettes for various formulations of molasses, clay and carbonized bagasse are presented in Table 3. The properties of clay that was used 
as a binder and those of wood charcoal produced using E. grandis and Kahawa coal are also given. Kahawa coal are briquettes produced by Kenya Planters Cooperative Union using coffee husks. They are currently in the market although in quantities that does not meet the demand.

Table 3. Average physico-chemical and energy properties of charcoal briquettes

\begin{tabular}{ccccccc}
\hline $\begin{array}{c}\text { Ratio of molasses: } \\
\text { clay: Bagasse }\end{array}$ & $\begin{array}{c}\text { Pressure, } \\
\text { N/mm2 }\end{array}$ & \multicolumn{3}{c}{ Physico-chemical properties, } & $\begin{array}{c}\text { Calorific energy, } \\
\text { Kcal/g }\end{array}$ \\
\cline { 3 - 6 } 1: 2: $\mathbf{2 0}$ & & M.C. & A.C. & V.M. & F.C.C & \\
& 0.25 & 4.1 & 51.3 & 23.0 & 25.7 & 2.684 \\
& 0.50 & 4.1 & 51.6 & 22.5 & 25.9 & 3.093 \\
& 0.75 & 4.5 & 47.0 & 24.0 & 29.0 & 3.338 \\
& 1.00 & 4.7 & 46.5 & 25.5 & 28.0 & 3.420. \\
\hline 1: 1: 40 & 0.25 & 4.3 & 40.1 & 23.5 & 36.4 & 4.105 \\
& $\mathbf{0 . 5 0}$ & $\mathbf{4 . 1}$ & $\mathbf{3 6 . 4}$ & $\mathbf{2 7 . 2}$ & $\mathbf{3 6 . 4}$ & $\mathbf{4 . 3 9 0}$ \\
& 0.75 & 4.1 & 40.4 & 23.9 & 36.1 & 4.053 \\
& 1.00 & 5.5 & 40.3 & 24.6 & 35.1 & 4.028 \\
\hline \multirow{2}{*}{ Clay } & & $\mathbf{2 . 8}$ & $\mathbf{9 0 . 1}$ & $\mathbf{5 . 7}$ & $\mathbf{4 . 2}$ & $\mathbf{0 . 6 1 9}$ \\
Kabawa coal & & $\mathbf{5 . 3 9}$ & $\mathbf{1 . 8 5}$ & $\mathbf{2 4 . 8}$ & $\mathbf{7 3 . 3}$ & $\mathbf{4 . 9 8 6}$ \\
\hline
\end{tabular}

M.C.- Moisture content; A.C.- Ash content; V.M. - Volatile matter; F.C.C. - Fixed carbon content

\section{Moisture content of charcoal briquettes}

The average moisture content of the briquettes was $4.7 \%$ for the $1: 2: 20$ formulation while it was $4.2 \%$ for the $1: 1: 40$ formulation with minimum and maximum moisture content of $4.1 \%$ and $4.7 \%$ respectively. Physico-chemical properties of clay that was used as a binder in the formulation of bagasse briquettes, those of wood charcoal and Kabawa coal were $2.8 \%, 5.4$ and $9.5 \%$ respectively at moisture content of less than $10 \%$. Their corresponding calorific energy values were $0.619 \mathrm{Kcal} / \mathrm{g}, 4.986 \mathrm{Kcal} / \mathrm{g}$ and $3.533 \mathrm{Kcal} / \mathrm{g}$.

At $18 \%$ moisture content and below, a material does not contain free water but water that is chemically bonded with a material, bound water. This means that so long as a material contains moisture content of less than $18 \%$, most of its physico-chemical properties would not be influenced by moisture content. However, it was important to analyse the various properties of charcoal briquettes at almost similar moisture content levels. The SABS (2000) recommends charcoal briquettes for household use to be analysed for these properties at moisture content not exceeding $10 \%$. 


\section{Volatile matter of charcoal briquettes}

The average volatile matter of briquettes produced using the $1: 2: 20$ formulation for molasses : clay : carbonized bagasse was $23.7 \%$ with a minimum of $22.5 \%$ at $0.50 \mathrm{~N} / \mathrm{mm}^{2}$ pressure and a maximum of $25.5 \%$ at $1.00 \mathrm{~N} / \mathrm{mm}^{2}$ pressure. The average volatile matter of the briquettes produced using the $1: 1: 40$ formulation was slightly higher at $24.1 \%$. This was because the amount of carbonized bagasse was higher in the $1: 1: 40$ formulation than in the $1: 2: 20$ formulation. The minimum and maximum volatile matter content for this formulation was $23.5 \%$ and $25.8 \%$ respectively. This compared very well with that of wood charcoal which was $24.8 \%$ and Kahawa coal which was $23.5 \%$. The proportion of volatile matter conformed with the quantity recommended by SABS (2000) which should not exceed $27 \%$.

It was found that the variation within average values of the briquettes produced using the same formulation with different pressures was not high. However, there was wide variation in average values of charcoal briquettes and clay. The average volatile matter due to clay was only $5.7 \%$ while that of charcoal ranged between a minimum of $22.5 \%$ and a maximum of $27.2 \%$. The minimal proportion of volatile matter in clay was expected because it is known to contain insignificant quantity of organic matter but predominantly inorganic particles. High proportion of volatile matter was attributed to the high proportion of organic matter in the material.

\section{Ash content of charcoal briquettes}

The average minimum and maximum ash content for the briquettes produced using $1: 2$ : 20 formulation was $46.5 \%$ and $51.6 \%$ respectively and $36.4 \%$ and $40.4 \%$ respectively for the $1: 1: 40$ formulation of molasses, clay and carbonized bagasse respectively. Clay was found to have very high proportion of ash content of $90.1 \%$.

The proportion of ash content was higher at all pressures for the $1: 2: 20$ formulation than for the $1: 1: 40$ formulation. This was because the former formulation contained high quantity of clay than the latter formulation. Briquettes produced with a formulation containing less clay released less ash content thus improving the quality of the briquettes.

Wood charcoal had very low ash content of $1.9 \%$ compared to that of Kahawa coal $(14.4 \%)$ and bagasse coal (36.4\%). It is advantageous when charcoal has a lower percentage of ash content since it saves on handling and disposal costs after the 
charcoal has been used for various economic purposes which is an advantage in terms of handling after use of the charcoal.

\section{Fixed carbon content of the briquettes}

The fixed carbon content of the briquettes produced followed closely the same pattern for the two formulations. It was higher for the $1: 1: 40$ formulation with the minimum and maximum being $35.7 \%$ and $37.8 \%$ respectively. For the $1: 2$ : 20 formulation the minimum and maximum fixed carbon content of the briquettes was $25.7 \%$ and $29.0 \%$ respectively. The fixed carbon content of the wood charcoal was significantly high at $73.3 \%$ which was more than twice that of the briquettes while that of Kahawa coal was also fairly high at $62.5 \%$.

Clay had very low fixed content of $7.1 \%$ making it tend to prolong cooking time by its low heat release (bake-oven effect). It also reduced the calorific energy of the briquettes by causing what is called fuel-saving effect. The higher the fixed carbon content the better the charcoal produced because the corresponding calorific energy is usually high (FAO, 1995).

\section{Calorific energy of charcoal briquettes}

The calorific energy of the briquettes, which is heat of combustion and a strong indicator of the superiority of a biofuel, ranged between a minimum of 2.684 $\mathrm{Kcal} / \mathrm{g}$ and a maximum of $3.420 \mathrm{Kcal} / \mathrm{g}$ for the $1: 2: 20$ formulation. Their corresponding values for the $1: 1: 40$ formulation was $4.053 \mathrm{Kcal} / \mathrm{g}$ and 4.390 $\mathrm{Kcal} / \mathrm{g}$. In each of the formulations, briquettes piston-presed at a pressure of 0.50 $\mathrm{N} / \mathrm{mm}^{2}$ had the highest calorific energy. Wood charcoal had the highest calorific energy of $4.986 \mathrm{Kcal} / \mathrm{g}$ while that of Kahawa coal was only $3.533 \mathrm{Kcal} / \mathrm{g}$. Due to its relatively high bulk density, Kahawa coal was expected to generate higher heat of combustion which was not the case.

The contribution of clay towards generation of heat of combustion was appreciable, with calorific energy of $0.619 \mathrm{Kcal} / \mathrm{g}$. This was reflected in the differences in calorific energy values of bagasse as a biomass residue and that of charcoal briquettes formulated from carbonized bagasse and clay. While the calorific energy of the former is $5.04 \mathrm{Kcal} / \mathrm{g}$, it was only $4.390 \mathrm{Kcal} / \mathrm{g}$ at its best for the latter. This conformed with its low heat release characteristic in the process reducing the calorific energy of the briquettes. 
The charcoal briquettes produced with the $1: 1: 40$ formulation of molasses, clay and carbonized bagasse was found to have higher calorific energy values at all pressure levels than those produced with the $1: 2: 20$ formulation. This was attributed to the use of less clay in the $1: 1: 40$ formulation than in the $1: 2: 20$ formulation. Overall, the bake-oven effect and the fuel-saving effect of clay contributed towards the suitability of charcoal briquettes for household use, particularly house warming and for cooking food (FAO, 1995).

\section{Burning and utilization characteristics of charcoal}

Table 4 shows the burning characteristics of charcoal produced using carbonized bagasse and that produced from mature E. grandis and Kahawa coal. The characteristics reported include the time taken for the charcoal to light (ignite), the time it took the ignited charcoal to raise the temperature of water to boiling point and the time it took for the charcoal to extinguish. Other properties determined were the sparking intensity of the charcoal, its level of odour and smokeness, the flame intensity and the proportion of ash when the charcoal had extinguished.

Table 4. Burning and utilization characteristics of charcoal briquettes

\begin{tabular}{|c|c|c|c|c|c|}
\hline \multirow[t]{2}{*}{$\begin{array}{l}\text { Charcoal } \\
\text { briquettes }\end{array}$} & \multicolumn{3}{|c|}{$\begin{array}{l}\text { Time taken to } \\
\text { (minutes) }\end{array}$} & \multirow[t]{2}{*}{$\begin{array}{l}\text { Weight } \\
\text { of ash } \\
\text { (g) }\end{array}$} & \multirow[t]{2}{*}{ Burning characteristics } \\
\hline & $\begin{array}{l}\text { Light/ } \\
\text { ignite }\end{array}$ & Boil & $\begin{array}{l}\text { Extin- } \\
\text { guish }\end{array}$ & & \\
\hline $\begin{array}{l}\text { B1 }(1: 2: 20) \text { at } \\
0.25 \mathrm{~N} / \mathrm{mm}^{2}\end{array}$ & 15.20 & 18.19 & 25.50 & 420.73 & $\begin{array}{l}\text { Not smoky } \\
\text { Burns with a blue glowing flame }\end{array}$ \\
\hline $\begin{array}{l}\text { B2 }(1: 2: 20) \text { at } \\
0.50 \mathrm{~N} / \mathrm{mm}^{2}\end{array}$ & 8.45 & 10.03 & 49.11 & 518.67 & $\begin{array}{l}\text { No sparks produced } \\
\text { No irritating smell released }\end{array}$ \\
\hline $\begin{array}{l}\text { B3 }(1: 2: 20) \text { at } \\
0.75 \mathrm{~N} / \mathrm{mm}^{2}\end{array}$ & 8.35 & 9.59 & 45.22 & 434.75 & Ash remains intact on cooling \\
\hline
\end{tabular}




\begin{tabular}{|c|c|c|c|c|c|}
\hline $\begin{array}{l}\text { B4 (1:2:20) at } \\
1.00 \mathrm{~N} / \mathrm{mm}^{2}\end{array}$ & 6.40 & 10.24 & 49.40 & 421.61 & Releases sweet smell \\
\hline $\begin{array}{l}\text { B1 }(1: 1: 40) \text { at } \\
0.25 \mathrm{~N} / \mathrm{mm}^{2}\end{array}$ & 4.40 & 10.07 & 61.09 & 351.27 & $\begin{array}{l}\text { Not smoky } \\
\text { Burns with a blue glowing flame }\end{array}$ \\
\hline $\begin{array}{l}\text { B2 }(1: 1: 40) \text { at } \\
0.50 \mathrm{~N} / \mathrm{mm}^{2}\end{array}$ & 6.30 & 9.57 & 58.30 & 349.87 & $\begin{array}{l}\text { No sparks produced } \\
\text { No irritating smell released }\end{array}$ \\
\hline $\begin{array}{l}\text { B3 }(1: 1: 40) \text { at } \\
0.75 \mathrm{~N} / \mathrm{mm}^{2}\end{array}$ & 5.23 & 11.23 & 63.55 & 383.19 & $\begin{array}{l}\text { Ash remains intact on cooling } \\
\text { Releases sweet smell }\end{array}$ \\
\hline $\begin{array}{l}\text { B4 (1:1:40) at } \\
1.00 \mathrm{~N} / \mathrm{mm}^{2}\end{array}$ & 7.35 & 9.50 & 44.28 & 312.77 & \\
\hline \multicolumn{6}{|c|}{ Eucalyptus grandis charcoal } \\
\hline EG-C1 & 4.12 & 7.52 & 50.14 & 62.47 & Not smoky \\
\hline EG-C2 & 4.30 & 8.30 & 56.18 & 86.63 & Burns with orange glowing flame \\
\hline EG-C3 & 5.50 & 11.20 & 52.02 & 60.89 & Sparks produced \\
\hline EG-C4 & 5.05 & 10.29 & 49.07 & 63.61 & No irritating smell produced \\
\hline EG-C5 & 3.30 & 9.38 & 54.31 & 49.84 & Ash was loose on cooling \\
\hline EG-C6 & 4.41 & 6.30 & 51.30 & 45.26 & \\
\hline \multicolumn{6}{|l|}{ Kahawa coal } \\
\hline $\begin{array}{l}\text { KC-1 } \\
\text { KC-2 } \\
\text { KC-3 }\end{array}$ & & & & & $\begin{array}{l}\text { Very smoky } \\
\text { No sparks produced } \\
\text { Very pungent and irritating smell produced } \\
\text { Ash not loose on cooling }\end{array}$ \\
\hline
\end{tabular}


The duration it took for the charcoal briquettes to ignite varied significantly within the formulation $1: 2: 20$ at different pressures. The duration ranged between a minimum of about 7 minutes and a maximum of 15 minutes to light for the 1.00 $\mathrm{N} / \mathrm{mm}^{2}$ and $0.25 \mathrm{~N} / \mathrm{mm}^{2}$ respectively. However, there was no clear trend of the duration of burning with either increasing or decreasing pressure. This was an indication that pressure had minimal influence on the duration of lighting the briquettes. At low pressure the material voids are expected to be more pronounced than at higher pressure, making mobility or conduction of heat from one particle to another low.

The minimum and maximum the briquettes took to ignite was 4.40 minutes and 7.35 minutes respectively for the $1: 1: 40$ formulation. In almost all cases, it took less time for the briquettes produced using the $1: 1: 40$ formulation to light than those produced using $1: 2: 20$ formulation. This was an indication that the duration of lighting was influenced by the proportion of clay in the briquettes. The more the amount of clay the longer it took to light the charcoal briquettes. This was because clay tends to make the briquettes stiff and heavy and prevents movement of air within a material (World Encyclopedia, 2001).

Wood charcoal made from E. grandis was found to take the least duration during lighting. The minimum and maximum duration it took was 3 minutes and 5 minutes respectively. This made wood charcoal relatively better than briquettes when considered on the basis of lighting characteristics.

The duration it took for the $2000 \mathrm{ml}$ of water to boil was about 10 minutes for the briquettes except for samples of briquettes made from the $1: 2: 20$ formulation at $0.25 \mathrm{~N} / \mathrm{mm}^{2}$ which took 18 minutes. This was the same case with wood charcoal which raised the water temperature to boiling point within a range of between 6 minutes and 11 minutes.

It took an average of 60 minutes for the briquettes with 1: 1: 40 formulation to extinguish while it took almost 50 minutes with the $1: 2: 20$ formulation and the wood charcoal to extinguish. It was deduced that the higher the amount of clay used in briquettes as a binder the faster the charcoal briquettes extinguished, which was a disadvantage for the superiority of the briquettes. It was quite unexpected that wood charcoal would take almost the same amount of time as the briquettes of the 1: 1: 40 formulation to extinguish. 


\section{Other burning properties of charcoal}

Wood charcoal and briquettes made from the two formulations were not smoky, neither did they release any irritating smell unlike Kahawa coal which was very smoky and released highly pungent odour. This was because of maximum carbonization during which time all the volatile matter was released. However, the bagasse briquettes released some sweet aroma when cooling which was attributed to molasses; a by-product of sugar-cane refining process containing between 40 $50 \%$ sugar. But kahawa coal produced highly pungent and irritating smell, making it unsuitable for household use due to its propensity to cause indoor pollution.

The charcoal briquettes burnt with a blue glowing flame without sparks unlike wood charcoal which burnt with an orange glowing flame producing sparks. Charcoal which sparks a lot is not highly preferred for household use since the sparks are hazardous to human beings, especially to exposed delicate human organs like the eyes.

There was substantial amount of ash in the briquettes which was compact after they extinguished. The amount of ash was higher in all samples for the $1: 2: 20$ formulation than for the $1: 1: 40$ formulation due to higher proportion of clay used in the former than in the latter. It would be an advantage to reduce the quantity of clay used as long as the rest of the physico-chemical properties of the briquette were enhanced. The amount of ash in wood charcoal was loose after it extinguished.

\section{Acknowledgements}

We are highly indebted to the management of Kenya Forestry Research Institute (KEFRI) who financially supported this study through its Farm Forestry Programme. We are also gratify to the management of all the sugar factories in Western Kenya for there co-operation during data collection. The district forest officers and the management of the various categories of sawmills were very helpful in availing the necessary information. Last but not least we highly appreciate the contribution of the Centre Director, colleagues and the technical staff of the Forest Products Research Centre (Karura) of KEFRI for facilitating completion of this study. 


\section{References}

Emrich, W. (1984). Handbook of Charcoal Making: The Traditional and Industrial Methods. Solar Energy R\&D in the European Community. Series E, Energy from Biomass. Vol. 7. Dordrecht, Netherlands; D. Reidel Publishing Co.

FAO (1995). Industrial Charcoal Making. FAO Forestry Paper No. 63. Mechanical Wood Products Branch. Forest Industries Division. FAO Forestry Department

Government of Kenya (2002). Ministry of Energy. Study on Kenya's Energy Demand, Supply and Policy Strategy for Households, Small Scale Industries and Service Establishments. Kamfor Company Limited, Nairobi. Chapter 1, ppxiii-xviii

Massaquoi, J.G.M. (1990). Agricultural Residues as Energy Sources, In: Baghavan, M.R. and S. Kerekezi (eds), Energy for Rural Development; Proceedings of the United Nations Group of Experts on the Role of New and Renewable Sources of Energy in Intergrated Rural Development. United Nation, Stockholm, Sweden 22-26 January 1990. Zed Books Ltd. London. Chapter 6, pp76-85

Mwichabe, S. (1999). Environmental Problems in Kenya: Surviving a Spoiled Environment. Konrad Occasional Papers, East Africa. Konrad Adenauer Foundation. Nairobi, Kenya. Chapter 5, pp32-38

Onchieku, J.M., B.N. Chikamai and M.S. Rao (2005). Development of mathematical models for estimation of the quantity of some residues. In press South African Bureau of Standards (2000). Wood Charcoal and Charcoal Briquettes for Household use. South African Standard Specification. Edition 2.2; 2002. South African Bureau of Standards. South Africa

United Nations Environment Programme (2000). Industry and Environment. Sustainable Energy. UNEP Publication. Pp 4-11

World Energy Council (2003). Resources Overview. Focus on Renewable Energy, In: http:/www.worldenergy.org/ 